\title{
Reading Proclus and the Book of Causes: Notes on the Western Scholarly Networks and Debates
}

\author{
Dragos Calma \\ University College Dublin / Newman Centre for the Study of Religions, \\ Dublin
}

The majority of contributions reunited in this volume were first presented during the first of the three sessions of the conference "Les Éléments de théologie et le Livre des causes du ve au XVII ${ }^{\mathrm{e}}$ siècle". It took place at the École pratique des hautes études, Paris, on 13-14 November 2015, during the terrorist attacks. ${ }^{1}$ The second took place on 12-13 February 2016, and the third on 14-15-16 April 2016; all within the framework of the project LIBER (ANR13-PDOC-O018-01) which I directed between 2013 and 2017 at the École pratique des hautes études, Paris, and which generously financed these meetings and the publication of the proceedings. ${ }^{2}$ The conferences were organised by Marc Geoffroy and myself, under the auspices of Olivier Boulnois, Philippe Hoffmann, Ruedi Imbach, Zénon Kaluza and Dominique Poirel. I wish to acknowledge the important support of the following bodies in the organisation of the conference: École pratique des hautes études, Équipe "philosophie arabe" of the Centre "Jean Pépin" — CNRS (UMR 8230), Laboratoire d'études sur les monothéismes-CNRS (UMR 8584), Labex haStec (Laboratoire européen d' histoire et anthropologie des savoirs, des techniques et des croyances), Institut de recherche et d'histoire des textes—CNRs, Centre "Pierre Abélard"Université Paris Sorbonne.

Compared to the original program of the three conferences, minor thematic rearrangements have been made for publication. Irene Zavattero presented her paper during the second session and I presented mine during the third session of the conference. Stephen Gersh's paper will be published in the second volume and Isabelle Moulin's in the third volume. The paper by Barbara Bartocci was not delivered at the conference, yet I am happy to integrate it in the vol-

1 A description of the conference during those days is provided by G. Battagliero in Bulletin de philosophie médiévale $57 / 2015$.

2 The work for this volume has been accomplished within the framework of the ERC project NeoplAT (ERC_CoG_771640). 
ume. Andrea A. Robiglio delivered a paper but could send it for publication. I wish to express my deepest gratitude to all the scholars presenting and / or publishing their papers, and also to those who chaired the sessions: Philippe Hoffmann, Olivier Boulnois, Luca Bianchi and Richard Taylor.

Lastly, I wish to thank Evan King for his reliable support and useful remarks; Robert M. Berchman and John F. Finamore for accepting the publication of these proceedings in their series; Jennifer Pavelko of Brill for her help throughout this period of work; the École pratique des hautes études and the French National Research Agency for making possible the funding of these volumes.

Marc Geoffroy introduced the first in the series of three conferences by remarking that the Book of Causes is not the product of a school, but of a circle, the circle of Al-Kindī. Thus, the Book of Causes is the result of a collaborative effort directed toward intellectual projects, which were financed by caliphs for dynasties of learned people.

This historical background fully justified the topic of the first of the three sessions, and thus of the present volume. The topic of the various translations, modes of acculturation and adaptation of the Elements of Theology and the Book of Causes to the various traditions (Islamic, Byzantine, Latin, Hebrew) is obviously extremely important. ${ }^{3}$ Yet of all these traditions, their Latin reception is the most extensive, judging by the number of manuscripts transmitting these texts and the number of commentaries addressing them. The system of universities and religious schools developed in the Latin West offered unparalleled conditions of diffusion for these two works, as well as for all the other texts included in curricula, methodically taught and commented upon. Hence, the main objective of this volume is to bring new insights to our understanding of the teaching of the Elements of Theology and the Book of Causes.

The recent discovery of a corpus of commentaries on these two works attested the existence of an overlooked scholarly network developed in most intellectual centres across Europe. This still requires years of patient investigation, yet it has already become clear that Proclean metaphysics was much more widely diffused than scholars have previously assumed. But precisely how broadly was it disseminated? Where and how did it all begin? How did this network impact the history of Western philosophy? These are some of the main questions that the present volume intends to address through a variety of methods of investigation and without pretending to provide exhaustive answers.

3 The second session of the conference (organised in February 2016) was entirely devoted to it and we currently prepare the publication of these proceedings. 
The research conducted by the present contributions (as well as by those from the subsequent volumes) does not aim to reveal "bombshells". It aims to shed light on a network of authors, texts, institutions-in sum, a network of exegesis. It aims to shift the traditional divide, so often damaging for our field, between "minor" and "major" authors. At the same time, however, these contributions do not wish to eradicate, ignore or deny the differences in terms of breadth, depth and impact between authors, but to transfer our attention to another kind of approach, already assiduously pursued by many scholars. It is a more inclusive approach that accords as much weight to the study and description of manuscripts, the history of libraries, institutions, teaching methods and literary genres as it does to the analysis of doctrines and concepts. It is, in any case, the most appropriate manner to approach an overlooked exegetical tradition. This volume aims to enrich our understanding of the extent and the diversity in reception of Proclean metaphysics, mapping its presence in different intellectual environments and texts. Indeed, it considers a large variety of works and references: from commentaries and glosses on the Book of Causes and the Elements of Theology to quodlibetal disputations, commentaries on the Metaphysics, the Nicomachean Ethics and the Sentences and authors active at Oxford, Cambridge, Paris, Prague, Erfurt or Venice.

Within this context, Dominique Poirel's paper can serve as a guide for understanding a wider array of medieval texts, although it mainly arises from a particular reflection on the Book of Causes. Poirel circumscribes the definition of an exegetical tradition to a corpus of texts that are all commentaries on one work. The characteristics of such a tradition are articulated around three main elements: corpus of texts, commentary and work. Time is an essential dimension for determining a "corpus of texts", inasmuch as it enables one both to capture the entire tradition and to distinguish three phases of reception and interpretation of a work: the age of initiators, the age of continuators and the age of conservators. "Commentary" needs to be considered in a large sense, comprising continuous commentaries, irregular glosses, quaestiones, introductory accessus, explicative phrase, syllogistic reformulation or any other form of expression through which a text refers to and explicates another text. The unity and coherence of the corpus is provided by one authoritative work, around which all these various forms of exegesis gravitate. They are not disconnected from one another, but comprise a set of texts whose coherence is underpinned by explicit references and intertextuality. ${ }^{4}$

4 See also Calma 2016a, p. 21-22. 
Irene Caiazzo offers a systematic study of the first reception of the Book of Causes in the Latin West. The first explicit reference to the Book of Causes is in Alan of Lille's De fide catholica which, according to the latest scholarship, was written in southern France between 1179 and 1202, probably before April 1187. This specifies the terminus ante quem of the Latin translation of the Book of Causes, previously considered in more general terms in respect to the year of Gerard of Cremona's death (1187). Caiazzo then analyses various citations and explanations of the Book of Causes in texts from the late 12th century and early 13th century, concluding that manuscripts of the Book of Causes arrived in England shortly after its translation in Toledo. This is attested both by the citations from Alfred of Shareshill's De motu cordis and Alexander of Neckam's Speculum speculationum (the first to refer to the Book of Causes as an Aristotelian work), and by the oldest known manuscript containing the Aristotelian Corpus vetustius and the Book of Causes: Ms Oxford, Bodleian Library, Selden Supra 24.

Fiorella Retucci brings new insights into the presence of the Book of Causes in England by studying all explicit citations in Thomas of York's influential, yet still unedited, Sapientiale. Composed between 1250 and 1260 while Thomas was at Oxford and Cambridge, the Sapientiale contains one hundred four explicit references to the Book of Causes (and four in a primitive draft), using twenty-two out of thirty-one (thirty-two) propositions. Retucci shows that Thomas of York, unlike many of his contemporaries, did not attribute the Book of Causes to Aristotle (at least not the theorems) because he understood that it belongs to the Platonic tradition. One of his main arguments is that the metaphysical hierarchy linking the divine mind and the realm of material beings through intermediary causes is affirmed by Plato, Avicebron, and the Book of Causes, and is rejected by Aristotle. Retucci corrects a commonly held view among scholars that, according to Thomas of York, the Book of Causes had Christian origins. In reality, he attributed it to one of the sapientes mundi.

Laure Miolo studies the presence of the manuscripts of the Book of Causes and the Elements of Theology in the libraries of Merton College (Oxford) and Peterhouse (Cambridge). This method of investigation has already been successfully applied to the College of Sorbonne. The documents of the English colleges differ in that they concern the distribution of books both to masters in charge of teaching and to libraries. Although none of the preserved statutes of the Universities of Oxford and Cambridge mention the compulsory teaching of the Book of Causes, Miolo finds evidence that the manuscripts preserving it were read and diffused. Miolo even hypothesizes that it may have been taught, given that the English masters, unlike the Parisians, had more freedom 
in choosing the texts to comment upon. Comparing her two analyses of the colleges of Paris, and of Cambridge and Oxford, Miolo concludes that, strictly on the basis of the presence of the manuscripts in libraries, the Book of Causes and the Elements of Theology were more widely diffused at Merton and Peterhouse than at the Sorbonne.

Olga Weijers undertakes a very detailed examination of all marginal glosses from the Parisian manuscripts transmitting the text of the Book of Causes. Thus she considers thirty-four manuscripts, most of them preserving the entire Aristotelian corpus. In four of them, the Book of Causes is accompanied by short continuous commentaries. In eight it is explained by rare marginal glosses. In the remaining twenty-two, there are very few or no glosses at all. Some of these marginal notes are copied from Aquinas' commentary on the De causis, which dates them later than the period when the text was originally copied. The result of this investigation is at once surprising and disappointing for two reasons. (1) The 1255 statute of Faculty of arts from the University of Paris is currently the only known official document prescribing the teaching of the Book of Causes. (2) Historians of philosophy have constantly assumed that the University of Paris was the main centre of interest for Proclean metaphysics. As Weijers notes, the results of her analysis need to be considered in relation with Miolo's work on the libraries of Parisian colleges. ${ }^{5}$ Nevertheless, one can already underline that these glosses attest Aquinas' influence on the exegetical tradition.

Katja Krause and Henryk Anzulewicz analyse the importance of the Book of Causes in Albert the Great's work prior to his famous paraphrases-commentary. They distinguish three stages. (1) The pre-Parisian period: very rare citations, in theological works, all of them in favour of various Christian doctrines. Albert uses only six of the thirty-one (thirty-two) theorems. (2) The Parisian period: an increase in the use of the Book of Causes, cited to support various arguments, but notably about the understanding of the world's coming-to-be. (3) The third phase: the period of the Commentary on the Sentences, where the Book of Causes gains more significance, especially by playing a decisive role in the division of the sciences of theology and philosophy. Krause and Anzulewicz clarify the complex question of the relationship between angels and intelligences in Albert's thought, and prove that the Book of Causes played a central role in this issue. The presence of the Book of Causes in the thought of Albert the Great gradually increased, eventually becoming an important element in his program of commenting on all of Aristotle's works.

5 Miolo 2016. 
Maria Evelina Malgieri examines some rare references to the fourth theorem of the Book of Causes which identify it as the "first" theorem. Only Henry of Ghent (twice in his Summa) and an anonymous (?) commentator on the Metaphysics use this unusual reference. Malgieri excludes the possibilities that these are due to errors by copyists and that they reflect a faulty model in the numbering of the Book of Causes' theorems. She claims that these references have an "evaluative connotation" because of the doctrinal relevance of the fourth theorem within debates on transcendentals. Analysing the details of the argumentation, she argues that both Henry of Ghent and the anonymous (if indeed they are two different individuals) use the fourth theorem in a context different than that of the standard arguments in the debates between a hypostatic and a noetic interpretation of the expression "the first of created things is being". It is conscious choice that arises in the discussion on the relationship between "being", "one" and "true". Malgieri is currently preparing the edition of this commentary on the Metaphysics.

The importance that Henry of Ghent accorded to the Book of Causes may have been one of the reasons for Duns Scotus' lack of interest for and critical attacks on it, as Jean-Michel Counet argues in his article. He shows that Duns Scotus' citations of the Book of Causes are rare and limited to a few theorems. This does not mean that the Franciscan was not interested in the topics elaborated in the opuscule, but that he does not consider necessary to cite it for them. Scotus seems to be interested mostly in theorems I and XXXI(XXXII). The latter is cited in discussions on the plurality of substantial forms. The former is used to affirm that the primary cause can restrain its virtue in order to produce an effect similar to that of the secondary cause, as well as to support the Filioque, arguing that the first theorem is valid only when applied to causes essentially subordinated to one another, which is not applicable in the case of the hypostases of the Holy Trinity.

Dragos Calma revisits Siger of Brabant's criticism of the occasionalists. He situates it in the context of the Siger's commentary on the Book of Causes, notably in a lengthy discussion underlining the role of secondary intelligences in respect to the operations of the first cause. Siger explicitly cites Averroes' critique of the moderni (i.e. the Ash'arites) and argues that the first theorem's doctrine about a primary cause pouring forth more abundantly than the secondary on its effect should not be interpreted as "without the secondary". One of the many doctrinal consequences of this incorrect understanding of the first theorem is Aquinas' theory of transubstantiation. Authors prior to Siger commented upon the first theorem in another manner than the commentators after Siger. At least four Latin authors, in their commentaries on the Book of Causes, relate the first theorem's expression plus influere to sine secundaria, 
using Siger's vocabulary, thesis and citations. Only one of them, Radulphus Brito, discusses the theory of the separability of accidents. Étienne Tempier and his theological commission in 1277 censured most of the themes deriving from the doctrine endorsed by Siger.

Iulia Székely identified sixteen unpublished quodlibetal questions from the Universities of Prague and Erfurt commenting on various theorems of the Book of Causes. She already co-edited two of them (by Henry of Geismar and Jan Arsen de Langenfeld) and, in the appendix of the present article, she provides the edition of another quodlibet. There are at least five major differences between the 15th-century Central European quodlibets and the more well-known 13th-century Parisian quodlibets: the institutional framework, the frequency and the length of the disputes, the planning of the event, its structure, its participants. Their choice of topics mirrors the most ardent discussions of the Faculty of arts, covering wider theological and philosophical interests. Székely describes four quodlibets and focuses on the reception in these late medieval Central European quodlibets of views elaborated in 13th-century commentaries on the Book of Causes, such as pseudo-Adam of Bocfeld's theory of plus influere and Siger of Brabant's discussion of sine secundaria.

Irene Zavattero studies the Latin reception of the Proclean doctrine of the three stages of the universal through Eustratius of Nicaea. Elaborated by Proclus in theorems 66-69 of the Elements of Theology, this theory is used, with important alterations, by Eustratius while commenting on Nicomachean Ethics I, 4. Zavattero shows that before the translation of Eustratius into Latin, some early Parisian masters defend Plato's theory of the universal Good against Aristotle's critique by evoking the concord between Christian doctrines, pseudoDionysius and the Book of Causes. After Moerbecke's translation, Plato's doctrine is defended with the arguments from Eustratius, which are quoted on both sides of the Channel: at Oxford by Richard Kilwardby in his De ortu scientiarum and by Thomas of York in his Sapientiale, and on the Continent by Albert the Great, Henry of Bate, Walter Burley and Berthold of Moosburg. Nevertheless, it can be shown that after Aquinas, the Parisian masters commenting on the Nicomachean Ethics lost their interest in Eustratius.

Guy Guldentops offers a thematic overview of Henry Bate's references to the Elements of Theology. He shows that Bate harmonizes Plato and Aristotle through Proclus, adopting an original approach that, on the one hand, elaborates a Neoplatonic interpretation of Aristotle and, on the other hand, provides a simplified account of Proclus' metaphysics. In many aspects, Bate seems to be closer to a monotheist Aristotelianism, which recalls the initial project of the Book of Causes. For his doctrine of the Good, for example, Bate chooses to interpret Proclus in correlation with pseudo-Dionysius and Aquinas, and 
even with the Book of Causes. According to this view, the first cause contains in itself all divine henads, similar to the divine ideas described by Augustine. Bate calls these henads rationes primordiales or species ideales. The first cause is equally One, Being and Good. Nevertheless, Guldentops stresses that Bate does not want to Christianise Proclus.

Ruedi Imbach's article is a stimulating dialogue with Olivier Boulnois' Métaphysiques rebelles, which challenges Heidegger's decontextualised reconstruction of ontotheology in Western philosophy. Boulnois' main argument is that metaphysics in the Middle Ages knew a variety of forms that can be classified in three groups: theo-logic, katholou-protologic and onto-theology. Imbach argues in favour of a simultaneity of these metaphysical models (unlike Boulnois who suggests that there is a progression) and identifies in Berthold of Moosburg's philosophical project a fourth type that can be called agathotheology, where priority is given to the Good in respect to the One. Building on Proclus' theology, Berthold's project goes beyond metaphysics in its Aristotelian framework. The Proclean wisdom elaborated in the Elements of Theology, put under the auspices of St. Paul's Rom. 1,20, is an authentic science about the principles of being, a science beyond being. Hence it is a science superior to metaphysics, a supersapientia and also a scientia divina philosophorum.

Evan King explicates the intricate questions of manuscript attributions and adaptations that enabled the most extensive reception of Eriugena in the Middle Ages: that of Berthold of Moosburg in his commentary on the Elements of Theology. Without these Eriugenian themes and citations, Berthold would not have succeeded in his project, in many respects inherited from Albert the Great and Dietrich of Freiberg, of establishing a broad consensus of Platonism, encompassing both the Hellenic Pagan tradition (Proclus) and the Christian tradition deriving from St. Paul (pseudo-Dionysius and imaginary Byzantine authors, such Theodorus Constantinopolitanus, in reality Honorius Augustodunensis, and Maximus monachus commentator Dionysii, in reality the Periphyseon as excerpted in the Parisian Corpus Dionysiacum). This patient reconstruction of sources represents an erudite foundation for an analysis of Berthold's interpretation of one of the most challenging features of the Elements of Theology for a Christian commentator: the doctrine of the incorruptible vehicle of the soul.

Zénon Kaluza offers a very detailed description and analysis of Giles Charlier's Quaestio collativa of the Principium from his Commentary on the Sentences. It is a theological text presented as a series of public lectures held at the College of Cambrai in 1416-1417, following all the rules of a scholarly commentary of this genre. The use of Proclus in a commentary on the Sentences is a rarity, and Kaluza's study of the context and the doctrines provides interest- 
ing explanations: the text was composed within the circle of Parisian masters and students, theologians as well as artists, known today as "Albertists", such as John of Nova Domo and Heymericus de Campo. Kaluza is persuaded that the latter was present in the room when Charlier read the Sentences. Proclus is a constant, though not massive, presence in the Commentary. He is cited more often than all the other authors from the Platonic tradition, which comprises pseudo-Dionysius, Boethius, the Book of Causes and Plato. Kaluza summarises some of the salient doctrines of the Quaestio collativa, such as the doctrine of God as highest Good, which creates all things and also distributes in them the longing to return to their creator. Thus Charlier introduces a notion of double causality, efficient and formal. Good is the trace left by God in all creatures through creation; it represents the ontological foundation of all creatures.

Barbara Bartocci studies how different commentators, from Proclus to Contarini, viewed Plato's Parmenides. She distinguishes several perspectives: some considered the hypothesis on the One as logical exercises, others as a mere eristic work, and others still as a metaphysical or theological treatise. The latter position is endorsed by the Hellenic Neoplatonists (Plotinus, Syrianus and Proclus). Nicholas of Cusa, who held three of the six manuscripts of Proclus' commentary, endorsed, in his Apologia doctae ignorantiae, the metaphysical explanation. Pico was firmly convinced of the concord between Plato and Aristotle, both holding that Being is identified with the One. Therefore, Pico refused the theological interpretation of the Parmenides in favour of viewing it as a dialectical exegesis. Ficino endorses the opposite position: in this dialogue Plato explains his ultimate view about the superiority of the One to the Being. Thus for Ficino it is definitely not a logical game. Bartocci summarises the major topics of Contarini's Primae philosophiae compendium showing that he holds a transcendental understanding of Being and One. For Contarini, the Platonists are not representatives of an ancient wisdom but provide examples of erroneous interpretations.

In addition to the individual contributions of each article, this collection as a whole provides a fresh understanding of several subjects, some of which are listed below.

1) The "centre" and the "peripheries". It is commonly accepted view that Proclean metaphysics was confined until around 1277 to the "centre", i.e. to the University of Paris, and in the 14th century to the "peripheries", i.e. the German authors such as the Dominicans of the so-called Albertschule 
and Nicholas of Cusa. Two previously published volumes ${ }^{6}$ have vigorously challenged this view by providing irrefutable proofs that (1) commentaries on the Book of Causes have been composed at the University of Paris long after 1277, and that (2) commentaries on the Book of Causes and the Elements of Theology were composed in numerous Central European Universities from the 14th to the 16th century. The present volumes brings further evidence that (1) the Book of Causes and the Elements of Theology were read and cited in Oxford and Cambridge already at the end of the 12th century and throughout the 13th century (cf. Caiazzo, Retucci and Miolo), and that (2) there is a clear interest for the Book of Causes at the Universities of Erfurt and Prague in the 15th century, as attested by various extracurricular quodlibetal disputations (cf. Székely). Remarkably, none of the statutes of the Universities of Oxford, Cambridge, Erfurt and Prague explicitly prescribed the teaching of the Book of Causes or the Elements of Theology. The Renaissance sees the interests of Latin authors extended to other Neoplatonic works, which they comment upon while citing one another (cf. Bartocci).

2) Local and global exegetical traditions. The comparison of texts produced in similar or different intellectual environments during a short period of time isolates defining features, such as the use of a "stock arguments", ${ }^{7}$ as well as influential authors. The uses of Siger's argument about sine secundaria in later commentaries (cf. Calma, Székely) or the quotations from Aquinas' commentary in marginal glosses (cf. Weijers) are notable examples. The existence of specific local traditions shaped by the use of the same libraries, of mutual and unusual citations, by the practice of the same form of teaching or by extracurricular academic activities, is undeniable. Yet these local traditions must be considered in a broader context in order to uncover the routes connecting authors, texts and institutions. One finds an example of this in the reinterpretation of Proclus in Byzantium, which is transmitted on the both sides of the Channel through Eustratius of Nicaea's Commentary on the Ethics (cf. Zavattero). The volume also studies the example of the transfer of specifically Parisian doctrines to Central European universities, such as Siger's arguments on sine secundaria, as well as the statutes of faculties and formal academic events. The universities and other regular teaching institutions are naturally the

6 Calma 2016; see also Calma 2012.

7 Cf. Bianchi 2017, p. 142. 
privileged place for the development of this exegetical tradition, but one has to note its presence outside this framework and in other literary genres, such as encyclopaedias (cf. Guldentops, Poirel).

3) New texts. The corpus of commentaries on the Book of Causes and the Elements of Theology is largely unexplored: the great majority of texts are still unpublished. Considerable efforts have been made, ${ }^{8}$ and we cannot but rejoice that this volume offers two new texts: the partial edition of Javelli Chrysostomus' commentary on the first theorem (cf. Poirel) ${ }^{9}$ and a quodlibetal question of Simon of Tišnov (cf. Székely). The analysis and descriptions of Giles Charliers' Quaestio collativa (cf. Kaluza), of the Anonymous' Commentary on the Metaphysics (cf. Malgieri) and of the marginal glosses in the Parisian manuscripts provide thorough discussions of texts which are still unpublished.

4) Theological dialogues in contrasting traditions. Until now, the standard view of many handbooks and compendia of Medieval Philosophy has been that, before Aquinas' commentary, the Book of Causes was associated with the Aristotelian tradition. The Book of Causes was indeed attributed to Aristotle already by Alexander Neckham and the majority of manuscripts from Paris, Oxford and Cambridge that transmit the text alongside the Aristotelian corpus. Yet numerous authors refer to the Book of Causes either without mentioning its author (e.g., Alan of Lille) or clearly refusing to link it to the Aristotelian tradition (e.g., Thomas of York). Then there is the remarkable use of the Book of Causes and the Elements of Theology in relation to numerous Christian theological arguments. This is not always a reflection of the need to Christianise Aristotle - as it is currently argued — but, on the contrary, of the need of Christianising Plato or to show the continuity and consistency between Platonists, both Pagan and Christian (such as in the case of Thomas of York, Berthold of Moosburg and Giles Charlier). Admittedly, this latter view is rather scarce but, for this reason, it is particularly interesting. Nevertheless, the present volume repeatedly stresses the presence of the Book of Causes and the Elements of Theology in specifically Christian theological works such as the Commentaries on the Sentences (Albert the Great, Thomas Aquinas and Giles Charlier) and treatises on De incarnatione and De resurrectione (Albert the Great). They are also cited in relation with specifically Christian doctrines, from sacramental theology

8 See Calma 2016.

9 Javelli Chrysostomus' commentary was already published at the beginning of the 16th century, but Dominique Poirel's thorough editing work renders the text more accessible. 
such as in Albert's discussion about the order of sacraments (cf. Krause, Anzulewicz), Aquinas' explanation of transubstantiation, to Trinitarian theology as in Duns Scotus' defence of the Filioque (cf. Counet), Berthold of Moosburg's theory of the resurrection of the body and the concord with St. Paul's heritage (cf. King and Imbach), without forgetting Étienne Tempier's reaction in 1277 (cf. Calma). ${ }^{10}$

5) New questions. The volume opens several paths of research. In these concluding remarks, I shall indicate only one of them, which itself arises from a paradox. The presence of the Book of Causes and the Elements of Theology in Oxford and Cambridge, although attested by these studies, stands in contrast with the lack of commentaries produced in these intellectual environments. In the present state of research it is difficult to offer a satisfactory answer to this issue. There are various reasons for this. For example, there is no scholarly consensus about the dating and the provenance of Roger Bacon's commentary on the Book of Causes: some assume that it is Paris, others that it is Oxford. ${ }^{11}$ The commentary attributed to Adam of Bocfeld has been recently evaluated both for its dating and its attribution: it was written between 1251 and $1263 / 1265$, probably by an author whose works have been wrongly attributed to Roger Bacon. It is still uncertain where the text was composed. Similarly, little is known about the two anonymous commentaries on the Book of Causes preserved in Ms Peterhouse $152 .{ }^{12}$ Most importantly, the newly discovered corpus of commentaries may reveal, upon closer examination, elements that would enrich our understanding about the transmission of Proclean metaphysics through the scholarly networks of the West.

\author{
Cambridge \\ 25 March 2018
}

\title{
Bibliography
}

Bianchi, L. (2017), "Boèce de Dacie et Averroès: essai d'un bilan", in D. Calma, Z. Kaluza (eds), Regards sur les traditions philosophiques (XII $-X V I^{e}$ siècles), Leuven, Leuven University Press, p. 127-152.

10 See also the use of the Book of Causes by Guillaume de Leus (Carron 2016).

11 See my contribution in this volume, n. 6.

12 See Miolo's contribution in this volume. 
Calma, D. (2012), "Du néoplatonisme au réalisme et retour, parcours latins du Liber de causis aux XIII ${ }^{\mathrm{e}}-\mathrm{XVI}^{\mathrm{e}}$ siècles", in Bulletin de philosophie médiévale, 54 (2012), p. 217276.

Calma, D. (ed.) (2016), Neoplatonism in the Middle Ages. Vol. I. New Commentaries on Liber de causis (ca. 1250-1350), Turnhout, Brepols. Vol. II. New Commentaries on Liber de causis and Elementatio theologica (ca. 1350-1500), Turnhout, Brepols.

Calma, D. (2016a), "The Exegetical Tradition of the Medieval Neoplatonism: Considerations on a Recently Discovered Corpus of Texts", in Calma 2016-1, p. 11-52.

Carron, D. (2016), "A Theological Reading of the Liber de causis at the Turn of the Fourteenth Century: The Example of William of Leus", in Calma 2016-1, p. 467-550.

Miolo, L. (2016), "Liber de causis in libraria. Pour une mise en perspective du Liber de causis dans la bibliothèque du collège de Sorbonne", in Calma 2016-2, p. 337-400. 